\title{
FINANCING INFRASTRUCTURE IN DEVELOPING COUNTRIES: LESSONS FROM THE RAILWAY AGE
}

\author{
Barry Eichengreen Pand
}

In recent years suggestions for reforming the provision and financing of infrastructure services in developing countries have focused on private participation. This alternative to public financing is seen as a way both to minimize the inefficiencies of public administration and to avoid the need for external borrowing.

In fact, for much of the nineteenth century, infrastructure projects were privately financed and built. This approach, however, did not obviate the need for government intervention and foreign capital. Because of the difficulties of assessing projects, investors were reluctant to commit their funds, and governments turned to subsidies and loan guarantees to encourage investment. Often, however, government intervention only replaced one set of problems with another. Investors with government-guaranteed loans had no incentive to monitor the firm's performance-a limitation that led to the diversion of funds and frustrated the public interest. This article draws out the implications of this experience for policymakers in developing countries today.

$\mathbf{F}$ or low-income countries, investments in infrastructure have alluring benefits as well as daunting costs. Where transportation, communication, and power generation are inadequate, increased supplies can do much to boost productivity and growth. But where income and productivity are depressed by inadequate infrastructure, the financial resources needed to underwrite investments are difficult to mobilize. Because the lack of infrastructure limits investment and the lack of investment limits infrastructure, low-income countries can find themselves in a low-level equilibrium trap from which it is difficult to escape.

Two potential escape routes-government subsidies and foreign borrowing-are available in principle. If infrastructure is critical for raising productivity and profitability elsewhere in the economy but those who finance the project cannot capture sufficient revenues to repay their costs, the classic effi-

The World Bank Research Observer, vol. 10, no. 1 (February 1995), pp. 75-91

(C) 1995 The International Bank for Reconstruction and Development/THE WORLD BANK 
cimry argunent for subsidies applies: that a subsidy that clossos the gap between private and social benefits will prevent the relevant form of infrastructure from being undersupplied. And even when the returns can be appropriated, investment may still not be attractive if high interest rates make domestic funds costly; investors may then seek finance abroad, where it is cheaper. Not surprisingly, government guarantees and foreign borrowing are prominent features of infrastructure finance in many developing countries.

Increasingly, these arguments for government intervention and foreign borrowing are regarded with skepticism. The costly "white elephants" subsidized by governments have underscored doubts about the efficiency of public finance, and the debt-servicing difficulties of developing countries have raised questions about the efficacy of foreign borrowing. Both observations encourage an interest in proposals to commercialize and privatize infrastructure projects and to fund them by promoting the development of financial markets.

There is nothing new about these arguments or these reservations. Infrastructure projects were privately financed and constructed in virtually all the overseas regions of recent European settlement in the nineteenth century (which, for the purposes of this article, is assumed to extend to 1914). At the same time, however, government subsidies and external finance were integral to the process of developing infrastructure. Although early U.S. railways, to take a prominent example, were private undertakings, land grants and government guarantees subsidized their construction. Finance was raised abroad, mainly on the London capital market. This history suggests that private initiative should not be viewed as obviating the need for government guarantees and foreign finance.

This article elucidates these historical patterns of public intervention and external finance for infrastructure investment, with a particular emphasis on railways. Its premise is that these patterns are consequences of the structure of financial markets in countries in the early stages of economic development. Nineteenth-century infrastructure investments included canals, docks, electric power grids, sanitation systems, telegraph systems, tramways, and turnpikes, but railways-the most prominent and capital intensive of these investments-commanded center stage. Railways forged unified national markets, linked domestic producers to the expanding world economy, facilitated the development of mass-production techniques, and incubated modern management practices. ${ }^{1}$ The analysis therefore draws on the literature on nineteenth-century railway investment, focusing most notably on recent contributions such as Baskin (1988) and Carlos and Lewis (1992, forthcoming).

Government intervention, external finance, and debt-servicing difficulties are correlates of the imperfections in financial markets that impose a heavy burden on governments seeking to finance infrastructure projects. At the same time, government policies to overcome asymmetric information can encourage management to engage in bankruptcy for profit (a problem that Akerlof and Romer 1993 refer to as "looting"). This tradeoff between credit rationing and the risk of bankruptcy for profit is at the heart of this article. 
The article reviews the interaction of asymmetric information, moral hazard, and adverse selection and, in this context, describes the financial and economic environment in which nineteenth-century firms and governments operated. It then considers two arrangements-government guarantees and land grantsused to subsidize infrastructure investment and to attract foreign finance and describes how these arrangements worked to relax credit constraints and weaken the incentive for creditors to monitor management. The article concludes by drawing some implications for developing countries today.

\section{Theoretical Considerations}

According to the Modigliani-Miller theorem, investors should be indifferent to the composition of a firm's financial structure; if a firm is highly leveraged, investors can offset the risk by adjusting the composition of their portfolios. But in the real world there are several reasons why this strong result does not prevail. The relevant reason here is asymmetric information (see Keeton 1979 and Stiglitz and Weiss 1981). That is, the entrepreneur knows more about the probability of failure than do external investors. So long as all projects yield the same expected return and investors are risk-neutral (that is, they are willing to accept risk rather than pay to avoid it), entrepreneurs with riskier projects will be willing to pay more for external funds. Because their information is poor, lenders cannot discriminate among borrowers. To cover their risk, therefore, lenders raise interest rates, prompting entrepreneurs with safer projects to drop out of the pool of potential borrowers. (This is the problem of adverse selection.) Higher interest rates, in turn, encourage the borrower to take on riskier investments. (This is the problem of moral hazard.) Raising interest rates can therefore reduce the lender's expected return. Under these circumstances, lenders may ration credit.

In this model, credit rationing is driven by the riskiness of the underlying environment and the severity of the barriers to the dissemination of accurate information. The more costly it is to sort projects (and the more pervasive the informational asymmetries), the more serious the problems of adverse selection and moral hazard. Many developing countries fit these conditions: they are, for example, subject to terms-of-trade shocks and lack effective regulations requiring financial disclosure.

What pattern of finance is likely to emerge when information is asymmetric and conditions favor adverse selection and moral hazard? Entrepreneurs or promoters with risky but potentially profitable projects will be forced to rely on their own funds. The more limited the lender's information, the more capital promoters will have to subscribe before external finance can be obtained. De Meza and Webb (1987) show that the resulting level of investment will be socially suboptimal. Under ideal conditions (known as first-best equilibrium, in which all markets clear exactly, information is perfect, and there are no distortions), with risk-neutral investors, all projects that yield returns equal to the 
world rate of retirin will be undertakcn. Büt when information is distributed asymmetrically, some such projects will not be financed. In such cases, a government interest-rate subsidy or guarantee may effectively relax the credit constraint. The problem is that such an arrangement weakens the incentive for investors to monitor management performance, because bondholders are guaranteed a return. This may allow management to divert resources to nonproductive uses from which it benefits (Jensen and Meckling 1976). In the extreme, promoters may resort to bankruptcy for profit. That is, they compare the returns from the earnings of the firm with those they would receive by taking out funds until they exhaust the resources that are available under the interest guarantee and are forced to declare bankruptcy. Or they inflate accounting rates of return relative to economic returns to appear solvent and acquire additional debt to be invested in activities that provide a high cash flow that the owners can tap. Because the government guarantees set the process in motion by weakening the incentive for investors to monitor management performance, the taxpayer is left holding the bag. This problem is most acute where government guarantees are unconditional, where public oversight is lax (effective surveillance and regulation should prevent promoters from gambling that they can get away with this strategy), and where promoters and their confederates attach the least value to their reputations.

\section{Asymmetric Information and Investment in the Railway Age}

Early infrastructure projects in North America posed formidable information problems for investors. Three factors in particular were conducive to informational asymmetries: the novelty of the technologies, the uncertain prospects for local market growth, and the dearth of reputable promoters.

Technology. The lack of familiarity with the technologies and the paucity of experience outside England hindered investors' search for information. ${ }^{2}$ Hence, so prominent and profitable a project as the Erie Canal sent a powerful signal to the capital market. The canal was completed in 1825 at a total cost of $\$ 11$ million- $\$ 3$ million of which came from current sources and $\$ 8$ million from long-term loans. The project was able to meet interest payments on the debt in its first year of operation and was fully paid off within ten years. The Erie's success set off a canal-building boom that engulfed the mid-Atlantic and New England coasts. And yet the costs of building the canal were of only limited value to those estimating the costs of building a canal through the higher mountains in western Pennsylvania. It is not entirely surprising that Pennsylvania's canals turned out to be more expensive than anticipated.

Uncertainties. In areas such as the American West that had only recently appeared on maps, not even geography could be taken for granted. At a dinner thrown by the Lord Mayor of London, an English investor asked an American guest whether Cincinnati or Illinois was the larger city. Even when the location was known, potential profitability was not: the amount of traffic a railway 
could generate was contingent on the economic development of adjoining regions, which depended on such unknowns as the fertility of the soil, the reliability of the rainfall, and the extent of mineral reserves. ${ }^{3}$ Where the volume of traffic ultimately depended on these reserves, uncertainty posed a considerable risk. Construction of many North American railways was based on crude forecasts of coal or silver deposits. Where land had to be settled and cleared before it could be farmed, it took years before the need for transport networks caught up with the investment in railroad infrastructure. In Canada, for example, although railway construction peaked in the final decades of the nineteenth century, significant gains in wheat production and rail traffic did not occur until the second decade of the twentieth century (Ankli 1980).

Experience with promoters. In addition to evaluating the economic prospects of the project, investors had to assess the reputability of the promoter. Recently settled, sparsely populated regions were prime locations for fly-by-night operators who could strike "sweetheart" deals with construction companies that would permit them to siphon off resources, saddling the project with insupportable debts. Typically, the uncertainty was reduced by drawing on the expertise and information of local investors. Where industrial and commercial development was precocious, it was possible to finance infrastructure through limited partnerships of local residents. Because early canals, turnpikes, and railroads had modest capital requirements (by the standards of the long-distance rail lines that followed), a local partnership could raise the requisite capital.

\section{Local Finance}

Examples from New England illustrate the point. The region was the center of American textile manufacturing and hence of American industry in the early nineteenth century, as well as the heart of commerce, shipping, and whaling. A growing number of small industrial towns provided a fertile market for shorthaul railways (Chandler 1954). From the trade with China, Boston merchants learned how to use entrepreneurial and managerial techniques to overcome the long spans of time and distance (Johnson and Supple 1967). Much of New England's railway finance was raised the same way in which the region financed its textile mills, by relying on family, friends, and other personal contacts. Where contract enforcement was problematic and information was difficult to verify independently, the markets made heavy use of such links. Friends and associates vested their confidence in individual financiers with reputations for honest dealing who signaled their commitment by putting their own funds at risk (Baskin 1988, Lamoreaux 1986). As Johnson and Supple (1967, p. 338) put it, "investment tended to be a cumulative social process in an environment lacking an impersonal, national money market." Thus, the danger of looting by fly-by-night operators was correspondingly reduced. Local farmers, bankers, merchants, landowners, contractors, and manufacturers subscribed the majority of New England's early railway shares. Not only did such individuals have 
tavord acress to information, but thcy stowd o benefit from the transportation links. At the head of many early syndicates were textile producers seeking roads that would serve their mills and Boston merchants looking to railroads as a link with the hinterland market and the Great Lakes (Platt 1984).

That these projects were relatively modest (they connected Boston with nearby Portsmouth, New Hampshire, or Providence, Rhode Island) facilitated the local mobilization of capital. Even a more ambitious line built in the late 1830s and early 1840s, the Western Rail-Road linking Boston with Albany, raised most of its finance locally. ${ }^{4}$

Underdeveloped markets could, however, impede efforts to raise local finance. The attempt to market bonds for Canada's St. Lawrence and Atlantic Railway in the 1840s illustrates these difficulties: farmers who had no cash paid their subscriptions in the form of pork and eggs to feed the construction gangs. Some early U.S. railways similarly took subscriptions in the form of labor and materials (Cleveland and Powell 1912).

\section{External Finance}

This model of local finance was difficult to generalize because the capital requirements of early railways were more modest than those of subsequent projects, and the funds available in New England exceeded those of other regions. Elsewhere it was necessary to seek external finance. ${ }^{5}$ Such funds were not a substitute for local finance; local investors still had to subscribe to indicate their willingness to put their money where their mouths were. If locals put up funds, external investors could be confident that those in the best position to assess the needs of the project and monitor its progress and the actions of its promoters would do so.

When Boston began to invest in the railroads of the U.S. South and West in the 1840 s, personal ties played a significant role. Railroad men coming to Boston contacted merchants who had invested in earlier railways. The promoters invested their own money in the project as evidence of their commitment and talked friends and business acquaintances into investing as well, Long-term relations between entrepreneurs from the West and merchants from Boston and between the merchants and their contacts provided a conduit for information about investment projects and individual promoters.

Railway securities tended to be traded in distant markets before such trade developed in manufacturing and commercial concerns. Manufacturing used more exotic technologies, and commercial undertakings had less tangible assets (knowledge of customer requirements, for example), so investing in industry and commerce had to surmount even higher information hurdles. The railways were consequently among the first enterprises to access external finance on a significant scale (Baskin 1988). According to Adler (1970), as early as the 1830 s several lines around Philadelphia and in Virginia and North Carolina were able to market securities in London, attracting support from British investors famil- 
iar with financing rail networks. The pattern persisted: as late as 1914 railway securities accounted for perhaps half of all outstanding foreign investments in the United States. Foreign financing entailed the intermediation of specialized institutions that had grown up in the principal European financial centers to deal with information problems: issue houses, private banks, bill brokers, and financial investment companies. An illustration of the importance of these institutions in Britain is shown in table 1. British investment houses typically retained American agents familiar with the American economy and railway projects. They specialized in recommending high-quality foreign bonds, usually those of railroads that were well known and long established or were backed by the credit of a state government. To show that they had confidence in the project, these firms often bought the same bonds for their own portfolios. Most British investors followed their advice, limiting their purchases to a few large eastern companies that provided adequate information (Adler 1970).

Financial institutions were not the only conduits for surmounting information problems. Immigrant communities were another, as were specialized publications such as The American Railroad Journal and Poor's Manual of the Rail-

Table 1. The Proportion of Overseas New Issues Introduced by the Main Types of British Issuing Houses, 1870-1914

\begin{tabular}{|c|c|c|c|c|c|c|c|}
\hline Years & $\begin{array}{l}\text { Official } \\
\text { and semi- } \\
\text { official } \\
\text { agencies }\end{array}$ & $\begin{array}{l}\text { Private } \\
\text { banks }\end{array}$ & $\begin{array}{l}\text { Joint- } \\
\text { stock } \\
\text { banks }\end{array}$ & $\begin{array}{c}\text { Overseas } \\
\text { banks and } \\
\text { agencies }\end{array}$ & $\begin{array}{c}\text { Compan- } \\
\text { ies via } \\
\text { their } \\
\text { bankers }\end{array}$ & $\begin{array}{l}\text { Other } \\
\text { mediab }\end{array}$ & $\begin{array}{c}\text { Total } \\
\text { amount } \\
\text { issued } \\
\text { (millions } \\
\text { of } \\
\text { pounds) }\end{array}$ \\
\hline $1870-74$ & 1.8 & 53.0 & 4.4 & 9.6 & 18.2 & 13.0 & 390.6 \\
\hline $1875-79$ & 14.5 & 36.5 & 0.8 & 24.7 & 13.0 & 10.5 & 149.2 \\
\hline $1880-84$ & 6.7 & 38.5 & 3.3 & 14.1 & 26.7 & 10.7 & 355.3 \\
\hline $1885-89$ & 9.9 & 43.7 & 5.3 & 7.5 & 26.1 & 7.5 & 479.2 \\
\hline $1890-94$ & 10.4 & 46.4 & 9.0 & 8.8 & 19.6 & 5.8 & 349.6 \\
\hline $1895-99$ & 8.7 & 25.1 & 11.2 & 20.3 & 25.2 & 9.5 & 359.6 \\
\hline $1900-04$ & 27.4 & 19.2 & 17.8 & 14.4 & 16.7 & 4.5 & 258.2 \\
\hline $1905-09$ & 10.3 & 32.7 & 12.2 & 22.4 & 18.7 & 3.7 & 509.9 \\
\hline $1910-14$ & 8.3 & 35.2 & 17.4 & 18.8 & 17.5 & 2.8 & 738.8 \\
\hline \multicolumn{8}{|l|}{$1870-1914$} \\
\hline Average (percent) & 9.8 & 37.2 & 10.3 & 15.4 & 20.5 & 6.8 & 100.0 \\
\hline $\begin{array}{l}\text { Total amount } \\
\text { issued (millions } \\
\text { of pounds) }\end{array}$ & 355.0 & $1,354.0$ & 371.0 & 562.0 & 746.0 & 248.0 & $3,636.0$ \\
\hline
\end{tabular}

Note: Figures are percentages unless otherwise specified.

a. That is, merchant bankers.

b. Investment trust, 23 million pounds; finance, land, and property companies, 18 million pounds; special-purpose syndicates, 41 million pounds; issue house with stock exchange connections, 22 million pounds; companies as their own issuers, 13 million pounds; and miscellaneous issuers, 131 million pounds.

Source: Based on a table prepared by W. A. Brown published in The Economist (November 20, 1937) and reprinted in Balough $(1947$, p. 233). 
roads of the Inited States. Frum the 1960 Butioti investors organized themseives as the Council of Foreign Bondholders and the English Association of American Bond and Shareholders to collect information on arrears and negotiate with debtors (Wilkins 1989 and Eichengreen and Portes 1989). Protective associations were established in France, Germany, and Holland as well. Some foreign investors traded in the securities of small or obscure railways, which they obtained from jobbers and dealers who purchased blocks of stock in the United States for sale in Europe. But the vast majority of investors concentrated on firstclass securities issued by the London offices of prominent American railways and endorsed by British issue houses or banks.

The preferred financial instruments varied with economic and geographic distance. Nearby lenders, such as New Englanders lending to the Midwest, purchased common stock, because personal and business contacts provided a reliable flow of information. The short, inexpensive lines of central New York were able to supplement local subscriptions with sales of equity in New York City. (According to Chandler 1954, trading in these shares played a central role in the early development of the New York Stock Exchange.) A group of investors in New York State purchased a substantial block of shares in Canada's Welland Canal, built in the late 1820 s and 1830 s to circumvent Niagara Falls and open Montreal to the western trade. British investors sometimes purchased common stock as well, although the majority of their-as well as other investors'-holdings were in bonds which, as primary claims, were perceived as less risky (Lewis 1938, Wilkins 1989). Such bonds were secured by mortgages on the railroad's property or were guaranteed by the government. Many lines issued bonds that were convertible into stock at the holder's option, and such bonds eventually became the standard instruments for financing railways and other infrastructure projects (Chandler 1954). A very few railways, such as certain early southern lines, were able to issue stock, but the returns were guaranteed by cities such as Charleston and Savannah.

Normally, the regulations and surveillance of an organized stock market help to attenuate the moral hazard and adverse selection problems caused by poor information. But the institutions of the London market carried out these functions only to a limited extent. The ability of the London Stock Exchange to restrict trading in particular securities was constrained by competition from European and provincial exchanges as well as from outside brokers and socalled bucket shops (the nineteenth-century equivalent of modern discount brokers) (see Adler 1970, Wilkins 1989). Paish (1951, p. 4) notes that "before 1914 the [London] Stock Exchange made no attempt to restrict or control in any way the right to deal in any security, whether British or foreign. . . . It was in general more concerned with arrangements to ensure a reasonably free market in the securities than with the intrinsic merits of the company or with the adequacy or accuracy of the information provided."

This meant that the portfolio of projects to be financed grew riskier as interest rates rose. Promoters had an incentive to take on excessive debt because they 
stood to make huge profits if the venture succeeded but could lose no more than their equity stake if it failed. Contemporaries consequently complained that many worthwhile investment projects were unable to raise external funds, and this inability to obtain credit created an obvious argument for government intervention.

\section{Government Subsidies and Guarantees}

"When great schemes of public utility are brought before the country," the editors of The Economist wrote in 1858, "it is natural that the Government should extend its aid to such enterprises" (MacPherson 1955, p. 181). In the case of investments in infrastructure, government aid came in three forms: interest guarantees on bonded debt, subsidies, and aid-in-kind (often financed by a bond issue designated for the purpose or by earmarked revenues). Canadian governments borrowed $\$ 20$ million to build canals in the 1840s (Jenks 1938). In the United States, state governments spent $\$ 121$ million of the $\$ 195$ million allocated to canal construction between 1815 and 1860 ; private companies spent only $\$ 74$ million (Cranmer 1960). State and local governments were also key subscribers to the securities of early American railroads. Before 1840 nearly all East-West projects-both railways and canals-were financed by public bonds. Thus, in the 1830s the Commonwealth of Massachusetts took a onethird partnership in the Western Railroad Corporation of Massachusetts, which it financed by floating state paper in London (Platt 1984, p. 156), and the state of Ohio subscribed one share in its state's railroads for every two shares purchased by private investors (Chandler 1954). Only the early North-South railways and the Pennsylvania coal roads were paid for largely by bonds of private corporations; these lines were shorter and cheaper to build and more certain of regular traffic.

The classic efficiency argument for subsidization rests on externalities: that a project's social returns exceed its private returns. The historical literature supports the proposition that the railways were a source of positive externalities. Fogel's (1960) study of the Union Pacific Railroad in the United States, for example, estimated that the social return averaged 30 percent a year, two-anda-half times the private return. Yet it is not clear that private entrepreneurs were always unable to capture these returns. In many cases the promoter of an infrastructure project purchased adjoining lands whose productivity and value were enhanced by construction of the turnpike, canal, or railway. In others, textile mills and mercantile enterprises whose profits were boosted by infrastructure investments that moved a steady supply of raw materials to the factory and finished products to the market could be-and often were-owned by those who organized the infrastructure projects. This ability to capitalize on their investment clearly weakened the case for subsidization. ${ }^{6}$

A further justification for government intervention was the need to offset the imperfections in capital markets that resulted from asymmetric information. 
Even if inyestors could otherwisc capiure the social returns, incomplete information that led to credit rationing sometimes prevented them from doing so.

A very different explanation for government intervention is rent-seeking by those who stood to benefit from government subsidies and guarantees. Lewis and McKinnon (1987) argue that the Canadian Northern Railway may have been socially as well as privately unprofitable but those who stood to benefit from its construction succeeded in enlisting government subsidies for the project. Rent-seeking was certainly prevalent, but one need not dismiss it as unimportant in order to acknowledge that at least some government intervention was justified on other grounds.

\section{Government Guarantees}

Capital market constraints explain one form of subsidy commonly used for canal and railway construction in the nineteenth century-interest guarantees on government bonds. In India, for example, if a railway company did not attain a minimum rate of return of, say, 5 percent, the government made up the difference. The interest clause in the bond covenant was backed by the government's full powers of taxation. All of India's early railways were built under the terms of the guarantee.

Government guarantees were particularly important in attracting foreign investors, who found it difficult to obtain accurate information on railway projects in India. Without guarantees, infrastructure projects were considered impossible to finance. MacPherson (1955, p. 180) reports that because the North Bengal Company was refused a guarantee, it was unable to begin construction and was forced to return all deposits to shareholders. Once the guarantee was provided, however, India's railways had no difficulty raising funds abroad. "The motives of the British investors can be explained almost entirely in terms of the 5 percent guarantee of interest offered by the Indian Government. Indian bonds were regarded as perfectly safe; investors included widows, barristers, clergymen, bankers, and retired army officers."

Canal projects in Canada in the first half of the nineteenth century received government guarantees under the aegis of the British Colonial Office. Before 1849 attempts to build railways in Canada had foundered on the difficulty of raising capital. That year legislation was passed guaranteeing interest at no more than 6 percent on half of the bonds of any railway more than seventy-five miles long, provided that half of the line was already built (Easterbrook and Aitken 1956). ${ }^{7}$ The guarantee, which covered the principal as well as the interest, enabled Canadian railways to attract significant amounts of foreign finance (see tables 2 and 3). ${ }^{8}$ Funds for the Grand Trunk line were raised from individuals, municipalities, and contractors, but roughly half of its bonds were guaranteed and were heavily subscribed by British investors. The Canadian Pacific and the Grand Trunk Pacific also enjoyed public support. Glazebrook (1938) concluded that not one of these lines could have been built without government guarantees. 
Table 2. Distribution of Total Flow of Capital to Canada, 1900-14 (millions of dollars)

\begin{tabular}{lrrrc}
\hline Recipient & $\begin{array}{c}\text { All } \\
\text { countries }\end{array}$ & $\begin{array}{c}\text { Great } \\
\text { Britain }\end{array}$ & $\begin{array}{c}\text { United } \\
\text { States }\end{array}$ & $\begin{array}{c}\text { Other } \\
\text { countries }\end{array}$ \\
\hline Dominion and provincial governments & 179 & 175 & 4 &.. \\
Municipal governments & 260 & 200 & 60 &. \\
Railroads & 767 & 670 & 50 & 47 \\
Industrial & 630 & 420 & 180 & 30 \\
Land and timber & 305 & 80 & 145 & 80 \\
Mining & 125 & 65 & 60 &.. \\
Insurance & 82 & 32 & 50 &. \\
Other & 198 & 111 & 81 & 6 \\
$\quad$ Total & 2,546 & 1,753 & 630 & 163 \\
\hline
\end{tabular}

.. Negligible.

Source: Buckley (1955, p. 66).

Although the guarantees helped railway promoters to surmount credit rationing, they also weakened the incentive for investors to hold management accountable. Investors no longer stood to lose-or to lose as much--if promoters and their confederates diverted resources from productive uses, because the government promised to bail them out. In the extreme, this might encourage the construction of railway lines where there was no hope of generating sufficient traffic to service the debt that was incurred. More generally, it gave promoters an incentive to negotiate sweetheart deals with contractors that made it possible to channel cash into their own accounts. Such practices were difficult to detect because reasonable costs for idiosyncratic projects such as railways and canals are intrinsically difficult to ascertain. And because construction generated an

Table 3. Gross Construction Outlays in Major Transport Fields, Canada, 1901-30

\begin{tabular}{lrrrr}
\hline & Railways & Highways & $\begin{array}{c}\text { Canals and } \\
\text { Yarbors }\end{array}$ & Total \\
\hline A. Values (millions of dollars) & & & \\
1901-05 & 124.3 & 3.3 & 32.1 & 159.7 \\
$1906-10$ & 380.7 & 11.7 & 48.0 & 440.4 \\
$1911-15$ & 537.4 & 38.5 & 93.7 & 669.6 \\
$1916-20$ & 252.5 & 39.4 & 59.7 & 351.6 \\
$1921-25$ & 253.2 & 100.4 & 109.8 & 463.4 \\
1926-30 & 389.4 & 172.4 & 138.2 & 700.0 \\
B. Percentage distribution & & & \\
$1901-05$ & 77.8 & 2.1 & 20.1 & 100.0 \\
$1906-10$ & 86.4 & 2.7 & 10.1 & 100.0 \\
$1911-15$ & 80.3 & 5.7 & 14.0 & 100.0 \\
$1916-20$ & 71.8 & 11.2 & 16.9 & 100.0 \\
$1921-25$ & 54.6 & 21.7 & 23.7 & 100.0 \\
$1926-30$ & 55.5 & 24.6 & 19.7 & 100.0 \\
\hline
\end{tabular}

Source: Buckley $(1955$, p. 32). 
sbundant cash fiow, tire diversion of resources into the pockcts of the promoters was relatively easy to arrange. Moreover, many partnerships were temporary, so promoters had little reason to be deterred by considerations of reputation. Only those ultimately responsible for the financial liability-or more precisely, their elected representatives-had an incentive to monitor the accounts.

Thus the potential for looting was created. Bondholders, whose rate of return was guaranteed by the government, had little incentive to expend resources to determine whether promoters had identified a project capable of generating an adequate net revenue stream or whether contractors were siphoning off the project's resources. Only if government authorities monitored the actions of promoters and contractors and threatened them with legal sanctions did the latter have reason to be deterred. Although the problem of quantifying minimum construction costs makes the prevalence of looting difficult to establish, the qualitative evidence is suggestive. Of Canada's Great Western Railway, Jenks (1938) wrote that its directors, who enjoyed a government guarantee, sought not to minimize construction costs, but to finance the contractor and share in his profits. The history of Canada's Grand Trunk Railway provides additional gory details. Almost immediately upon floating government-guaranteed bonds, as Easterbrook and Aitken (1956, p. 309) noted, the company found itself unable to pay interest. To a large degree, its problems reflected "unanticipated costs of construction," as contractors pressed for new links to the railways of New York and Michigan rather than using existing lines. In 1851 Gzowski and Company, a contracting firm run by former directors of railways with connections to the Grand Trunk, was awarded the contract for the construction of these lines. The contractors were paid in cash, "and the individual members of the firm realized sizable fortunes" (p. 310). The British group of Peto, Brassey, Betts, and Jackson, itself deeply entangled in Canadian politics, was "helped . . . over every difficulty" by "a complaisant legislature and a winning governor-general" (Jenks 1938 , p. 204). Existing lines were added to the network for "inflated" purchase prices. Operating expenses in the first ten years ran between 58 and 85 percent of gross receipts-far above the 40 percent that had been forecast and was typical of other railways.

This type of fraud is consistent with the predictions of the Akerlof-Romer model-that government guarantees extended to relax credit-rationing constraints weaken the effectiveness of corporate control if they are not accompanied by effective public sector oversight and regulation. Currie $(1957$, p. 9) summarized the situation: "As the Government would guarantee bonds up to one-half the cost of the road, hard-pressed promoters were tempted to inflate their costs, to effectively force the Government to assume responsibility for more than its proper share of the actual expenditure, and to reduce the real value of the assets against which, under the Guarantee Act, the Government held a first mortgage."

In India there were layers of principal-agent problems: the taxpayers underwrote the guarantee, but the government that extended it was responsible not to 
them, but to the British Crown; Jenks (1938) attributes failed projects such as the Madras Canal, which was completed but could not be filled with water, to the lack of monitoring encouraged by this weak structure. Of the railways, he reports that an Indian finance minister testified, "All the money came from the English capitalist, and so long as he was guaranteed 5 percent on the revenues of India, it was immaterial to him whether the funds that he lent were thrown into the Hooghly [River] or converted into brick and mortar" (pp. 221-22).

\section{Land Grants}

Land grants, which served to correct capital market imperfections by providing collateral, were another prevalent form of government subsidy. Approximately 150 million acres of land were granted to western U.S. railways between 1850 and 1870. Legislation authorizing the use of land grants was adopted in Canada in 1852 , although it was not used until the 1870 s. Land grants were attractive on several counts. First, because the prairies in both countries were unsettled and the land remained in government hands, such grants obviated problems of assembling parcels for right-of-ways. Second, a land grant tended to confront less political resistance than did government financial subsidies and interest guarantees, which implied the imposition of distortionary taxes. Arguably, ceding land adjoining railways and canals to the promoters of those projects also allowed promoters to recover at least some of the externalities that were thrown off by their investments. Third, compared with other bonds, those backed by mortgages on land had minimal bankruptcy costs; the interest and principal due to the primary creditors could be paid off, at least in part, through the sale of the land if the project failed. The loan was collateralized, thus mitigating the moral hazard and adverse selection problems that otherwise constrain credit. ${ }^{9}$ Adler (1970) notes that the importance of this support is reflected in the fact that only American railroads receiving land grants were able to issue regular bonds (as opposed to convertible issues). Alternatively, receipts from the sales of land, known as "land income" bonds, could be mortgaged. In the case of the Atchison, Topeka and Santa Fe Railroad, this backing was attractive to foreign investors, who had limited opportunities for monitoring the project.

In principle, these land grants collateralized only a portion of an enterprise's bonded debt. Compared with an unlimited guarantee, this should have encouraged closer monitoring by outside investors. But in fact, railways that ran into difficulties were frequently offered additional guarantees and subsidies. In practice, it is questionable that the negative side effects of land grants were less pronounced than those of bond guarantees.

Fishlow (1965) estimates that the land subsidy amounted to roughly 5 percent of total railroad investment between 1850 and 1880; Mercer $(1969,1972)$ arrives at smaller numbers. The small size of these estimates suggests that land grants only partially collateralized the railways' liabilities. Land grants were not 
unifominy usisiuivucd, however; they were concentrated in the period 1865 to 1870 and were awarded disproportionately to certain risky investments, such as the first transcontinental lines. Mercer concludes that many land grants were wasted on railroads that would have been built in any case. He bases his view on the finding that the private rate of return exceeded the return on alternative uses of funds. In other words, the railways still would have wished to borrow at the prevailing rate. An asymmetric information perspective casts doubt on this conclusion, however, because it implies that, without land grants, some railways might not have been able to obtain external finance at any price.

\section{Policy Implications}

Recent suggestions for reforming the ways infrastructure in developing countries is provided and financed include encouraging private provision as a way to avoid the inefficiencies of public administration and tapping local savings as a way to avoid excessive reliance on external borrowing. These suggestions have a back-to-the-future quality: private provision and local finance were characteristic of infrastructure investments in many countries-notably the North American case considered here-for much of the nineteenth century. Consequently, the historical record is a potentially rich source of information on the circumstances under which these approaches are workable and on their limitations.

What the record reveals is that government intervention continued to be important. The ability of domestic financial markets to underwrite the construction of ports, canals, and railways was constrained, in part because of informational asymmetries characteristic of markets in the early stages of development. To help with these problems and to attract private investment, lenders turned to financial institutions that specialized in assessing projects and monitoring management. These were typically foreign institutions with foreign clienteles whose experience with privately financed projects had given them a head start in raising capital and judging risk. This approach relieved-but did not eliminate-concerns about inadequate information. Nor did private investment and local capital reduce the government's involvement or the need for foreign borrowing.

All too often, however, government intervention simply replaced one set of problems with another. Investors, assured of a guaranteed return, had less incentive to hold management accountable. Management, freed of investor scrutiny and provided with access to capital markets, courtesy of the government, arranged deals with construction companies that left taxpayers holding the bag. Guaranteed loans encouraged investors to finance infrastructure projects, but without built-in mechanisms to monitor spending and protect the public interest, it was impossible to ensure that resources were allocated efficiently.

These failings imply that exploiting nontraditional approaches to financing infrastructure requires two further policy initiatives. First, efforts should be made to enhance the effectiveness of public administration. Government agencies or departments should be responsible for monitoring the efficiency and 
performance of the enterprise and should be backed by a credible threat of sanctions against managers who are tempted to enrich themselves. Second, policymakers need to encourage the development of financial institutions and instruments such as banks, mutual funds, and bond-rating agencies that can surmount information problems and relieve the government of the need to provide subsidies and interest guarantees. ${ }^{10}$

These are essential tasks for governments in any setting. Idealistic strategies for privatizing the provision of infrastructure notwithstanding, it seems likely that government's traditional role-and the traditional problems associated with government intervention-will necessarily remain.

\section{Notes}

Barry Eichengreen is John L. Simpson professor of economics and professor of political science at the University of California, Berkeley. He would like to thank Ashoka Mody for guidance, Ann Carlos, Michael Edelstein, Frank Lewis, Richard Sylla, and Mira Wilkins for comments, and Lisa Ortiz and Andrea $\mathrm{Cu}$ for research assistance.

1. Fogel (1964), however, concludes that the social savings attributable to railway construction in the United States were small. Given geographical and topographical differences, subsequent studies have yielded larger estimates for other parts of the world. Nor do calculations of social savings attempt to quantify the dynamic effects emphasized by authors as diverse as Chandler (1990), Jenks (1944), and Williamson (1974).

2. Foreign investors were put off by political uncertainty as well. The disruption caused by the Civil War, for example, lingered into the $1870 \mathrm{~s}$.

3. The same was true elsewhere, of course. Thus, in 1852 the chairman of the Madras Company cited "want of local knowledge" as an obstacle to attracting external finance for railroads in India (MacPherson 1955, p. 180).

4. Although the Western Rail-Road had more than 2,000 shareholders, most of these were located in Boston. Only 17 percent had one hundred or more shares as of 1841 . To continue the road from the state line to Albany, the city of Albany subscribed the entire capital, paying for it with city bonds (Johnson and Supple 1967).

5. I refer to "external" rather than "foreign" finance for two reasons. First, entities such as Canada and India, which were not fully independent, relied on external finance from the imperial center, Great Britain. Second, regions that were late in developing, such as the western United States, relied on external finance from regions that had developed earlier, such as New England.

6. Because many different landowners and merchants typically benefited from the construction of a single railway line, the problems of organizing collective actions by a large number of vaguely interested parties might impede efforts to internalize the externalities, leaving a rationale for subsidization.

7. In 1851 the guarantee was restricted to railroads that formed part of a main, or trunk, line. This legislation was passed partly in response to pressure from the Canadian government's British bankers, Baring Brothers and Glyn, Mills and Company, who worried that an unlimited guarantee would encourage excessive building and result in an unsupportable debt. Another act, in 1852, liberalized this condition somewhat, allowing individual municipalities to borrow from a provincial fund to help establish branch and feeder lines (Currie 1957, p. 9).

8. An exception was the Great Western Railway, which obtained initial capital from merchants in Detroit and from New York investors who had financed the New York Central. Completion, however, required floating a bond in London in 1852. Other major railways 
initided after the passagc of tin Gudatuce Act relied aimost entrely on British finance (Carlos and Lewis, forthcoming).

9. This was true at least of early mortgage bonds. Subsequently, some promoters issued "collateral trust mortgage bonds" that were secured not by real property, but by the stocks and bonds of other companies. See Bryant (1971) for details.

10. The case for subsidization may only be reduced, rather than eliminated, insofar as infrastructure investments continue to throw off positive externalities that private agents cannot internalize fully. This distinguishes the problem of financing infrastructure investments from general problems of financing enterprises in developing countries.

\section{References}

Adler, Dorothy. 1970. British Investment in American Railways. 1834-1898. Charlottesville, Va.: University of Virginia Press.

Akerlof, George, and Paul Romer. 1993. "Looting: The Economic Underworld of Bankruptcy for Profit." Brookings Papers on Economic Activity 2:1-73.

Ankli, Robert E. 1980. “The Growth of the Canadian Economy, 1896-1920.” Explorations in Economic History 17:251-74.

Balough, Thomas. 1947. Studies in Financial Organization. Cambridge, U.K.: Cambridge University Press.

Baskin, Jonathan B. 1988. "The Development of Corporate Financial Markets in Britain and the United States, 1600-1914: Overcoming Asymmetric Information.” Business History Review 62:199-237.

Bryant, Keith L. 1971. Arthur E. Stilwell. Nashville, Tenn.: Vanderbilt University Press.

Buckley, K. A. H. 1955. Capital Formation in Canada 1896-1930. Toronto: University of Toronto Press.

Carlos, Ann M., and Frank D. Lewis. 1992. "The Profitability of Early Canadian Railroads: Evidence from the Grand Trunk and Great Western Railway Companies." In Claudia Goldin and Hugh Rockoff, eds., Strategic Factors in Nineteenth Century American Economic History. Chicago, Ill.: University of Chicago Press.

- Forthcoming. "Foreign Financing of Canadian Railroads: The Role of Information." In Michael D. Bordo and Richard Sylla, eds., Anglo-American Financial Systems: Institutions and Markets in the Twentieth-Century. Burr Ridge, Ill.: Irwin.

Chandler, Alfred. 1954. "Patterns of American Railroad Finance." Business History Review 28:248-63.

. 1990. Scale and Scope. Cambridge, Mass.: Harvard University Press.

Cleveland, Frederick A., and Fred Wilbur Powell. 1912. Railroad Finance. New York: D. Appleton.

Cranmer, H. Jerome. 1960. "Canal Investment, 1815-1860." In National Bureau of Economic Research, Trends in the American Economy in the 19th Century. Princeton, N.J.: Princeton University Press for the National Bureau of Economic Research.

Currie, A. W. 1957. The Grand Trunk Railway of Canada. Toronto: University of Toronto Press.

De Meza, David, and David C. Webb. 1987. "Too Much Investment: A Problem of Asymmetric Information." Quarterly Journal of Economics 102:281-91.

Easterbrook, W. T., and G. J. Aitken. 1956. Canadian Economic History. Toronto: University of Toronto Press.

Eichengreen, Barry, and Richard Portes. 1989. "After the Deluge: Default, Negotiation, and Readjustment on Defaulted Foreign Bonds During the Interwar Years." In Barry Eichengreen and Peter Lindert, eds., The International Debt Crisis in Historical Perspective. Cambridge, Mass.: MIT Press. 
Fishlow, Albert. 1965. American Railroads and the Transformation of the Antebellum Economy. Cañuridge, Mass.: Harvard University Press.

. 1986. "Lessons from the Past: Capital Markets and Foreign Lending During and 19th Century and the Interwar Period." In Miles Kahler, ed., The Politics of International Debt. Ithaca, N.Y.: Cornell University Press.

Fogel, Robert. 1960. The Union Pacific Railroad: A Case of Premature Enterprise. Baltimore, Md: Johns Hopkins University Press.

- 1964. Railroads and American Economic Growth. Baltimore, Md.: Johns Hopkins University Press.

Glazebrook, G. P. 1938. A History of Transportation in Canada. Toronto: McClelland and Stewart.

Jenks, Leland J. 1938. The Migration of British Capital to 1875. New York: Knopf.

- 1944. "Railroads as an Economic Force in American Development." Journal of Economic History 4:1-20.

Jensen, Michael C., and William H. Meckling. 1976. "Theory of the Firm: Managerial Behavior, Agency Costs and Ownership Structure." Journal of Financial Economics 3:305-60.

Johnson, Arthur H., and Barry E. Supple. 1967. Boston Capitalists and Western Railways. Cambridge, Mass.: Harvard University Press.

Keeton, William. 1979. Equilibrium Credit Rationing. New York: Garland Press.

Lamoreaux, Naomi. 1986. "Banks, Kinship, and Economic Development: The New England Case." Journal of Economic History 46:647-68.

Lewis, Cleona. 1938. America's Stake in International Investments. Washington, D.C.: The Brookings Institution.

Lewis, Frank, and Mary McKinnon. 1987. "Government Loan Guarantees and the Failure of the Canadian Northern Railway." Journal of Economic History 47:175-96.

MacPherson, W. J. 1955. "Investment In Indian Railways, 1845-1875." Economic History Review 8:177-86.

Mercer, Lloyd. 1969. "Land Grants to American Railroads: Social Cost or Social Benefit?" Business History Review 43:134-51.

- 1972. “Taxpayers or Investors: Who Paid for the Land Grant Railroads?" Business History Review 46:279-94.

Paish, F. W. 1951. “The London New Issue Market.” Economica 18:117.

Platt, D. C. M. 1984. Foreign Finance in Continental Europe and the United States 1815-1870. London: Allen \& Unwin.

Stiglitz, Joseph, and Andrew Weiss. 1981. "Credit Rationing in Markets with Imperfect Information." American Economic Review 71:393-410.

Wilkins, Mira. 1989. The History of Foreign Investment in the United States to 1914. Cambridge, Mass.: Harvard University Press.

Williamson, Jeffrey G. 1974. Late Nineteenth-Century Economic Development: A General Equilibrium Approach. New York: Cambridge University Press. 